\title{
The Advantages of Using Earnings for Compensation: Matching Delivered Performance
}

\author{
Michael J. Barclay \\ Simon School of Business \\ University of Rochester, Rochester, NY 14627 \\ Dan Gode ${ }^{*}$ \\ Stern School of Business \\ New York University, NY 10012 \\ S. P. Kothari \\ Sloan School of Management \\ MIT, Cambridge, MA 02142
}

First Draft: August 1995

Current version: June 2000

We acknowledge helpful comments of John Long, Suresh Radhakrishnan, Rajdeep Singh, Shyam Sunder, Jerry Zimmerman, and seminar participants at University of Arizona, CUNY Baruch, SUNY Buffalo, Columbia, Harvard Business School, University of Maryland, New York University, University of Rochester, Stanford University, University of Southern California, Tulane University, and Washington University. We thank the Bradley Policy Research Center and John M. Olin Foundation for financial support.

\footnotetext{
*Please send all correspondence to dgode@stern.nyu.edu

$8 / 1 / 2000$
} 


\section{Matching Delivered Performance}

Abstract

We show that the greater the extent to which a performance measure matches delivered performance, the simpler and more robust are the compensation plans based on it. In some settings stock price changes match delivered performance poorly because they anticipate it. This introduces three problems with price-based plans relative to an earnings-based plan. First, the price-based plans become complex because they require knowing the extent to which prices anticipate the future. Second, price-based plans are less robust to unforeseen events. Third, price-based plans require period-by-period changes in pay-for-performance relationship even when the underlying production function remains unchanged. Earnings-based plans are used in these settings if earnings better match delivered performance. 


\section{Introduction}

Economists have traditionally analyzed three prominent attributes of performance measures - informativeness, verifiability, and cost. These attributes, however, do not explain the choice of performance measures where alternative performance measures are equal over long horizons, but they differ over shorter periods (e.g., one year). Many economists are puzzled by the widespread use of earnings-based plans for top managers because it is argued that stock prices are more informative, easily verifiable, and less costly to observe. We argue that a fourth desirable attribute of performance measures - matching delivered performance - partially explains the use of earnings in compensation plans. We use the term "delivered performance" to denote the value added to the firm by a manager's current actions as against future actions regardless of how likely they are.

Most prior research argues that stock prices provide a better performance measure than earnings because accountants are conservative and managers can (and do) manipulate earnings. The are two arguments favoring earnings-based plans. First, earnings can provide disaggregate information about business units or tasks (Paul 1993). Second, stock prices contain "noise" such as the effect of macroeconomic factors beyond managerial control (Sloan 1993).

Our argument differs from, but does not contradict, those in the prior literature. We examine a single-task setting to eliminate the demand for disaggregate performance measures. We assume that earnings equal stock price changes over long horizons (see Easton, Harris, and Ohlson, 1992, for evidence), which means both prices and earnings are equally susceptible to the macroeconomic "noise" problem over the long run. Over short horizons, however, earnings and price changes are not equal and we examine he implications of their timing differences.

Our analysis shows that matching delivered performance is an important fourth attribute of performance measures that partially explains the use of earnings in CEO compensation plans when informative and verifiable stock prices are easily available. We argue that the extent to which performance measures match delivered performance is important, even if they have the same informativeness within each period and are identical over longer horizons. A performance measure that is matched to delivered performance is preferred because it leads to simpler and more robust contracts. 
Our analysis complements the analysis of Rogerson (1997) and Reichelstein (1997, 1999) who compare cash flows and accounting earnings, which differ only in their timing, and point out the virtues of applying the "matching principle" in a setting where a manager is privately informed about investment opportunities. We compare stock prices and earnings in a moral hazard setting and highlight the usefulness of a signal that matches delivered performance.

The following example illustrates why matching delivered performance is an important attribute of a performance measure. In January 1993, Christopher Steffen was appointed as the chief financial officer of the Eastman Kodak Company. Within two days of his appointment, Kodak's market value soared by about $\$ 2.2$ billion. The Wall Street Journal's "Heard on the Street" column (January 21, 1993) attributed much of the rise in Kodak's market value to changes anticipated under Steffen, citing his proven ability to cut costs. Three months later, Steffen resigned without accomplishing the anticipated cost-cutting and Kodak's market value dropped by about $\$ 2$ billion. A reasonable interpretation of this evidence is that the rise in Kodak's stock price in January 1993 reflected anticipated future performance that was not delivered. Thus, the stock price change in January 1993 was not a good measure of Steffen's (or anyone's) delivered performance. Another example is the rise and fall of Sunbeam's stock price with the arrival and departure of Al Dunlap.

Firms prefer performance measures that match delivered performance because of the constraints they face in designing contracts. For example, they do not want to pay their managers in advance because it is costly to recover prior payments, and up-front payments without ex-post settling up provide no incentives. Managers, on the other hand, do not want their compensation withheld for extended periods after they have worked because they are more "impatient" than the firm (Reichelstein 1999). ${ }^{1}$ Thus, firms contract with managers over horizons that are shorter than the life of many projects, which makes matching performance measures to delivered performance over the short run important, even if the measures are equally informative over the short run. Firms also prefer contracts that require less information in their design, are simpler in the sense

\footnotetext{
${ }^{1}$ A simple deferral of guaranteed compensation for tax reasons, such as pension plans, is not relevant to our paper. The greater the extent to which long-term incentive plans, such as restricted stock and non-vested option grants, where deferred payments are not vested and depend on long-term performance, can be used to extend contract duration, the less important is the timing difference between signals.
} 
that they require no changes in pay-for-performance relationship when the underlying task environment remains unchanged across time, and are robust to unforeseen events.

To compare price changes and earnings as performance measures, we consider a case where earnings match delivered performance each period, while prices, as usual, measure only the unanticipated component of delivered performance (because the anticipated component was already reflected in previous stock prices). We argue that a price-based plan has three problems. First, its design requires that the board of directors know the extent to which prices anticipate delivered performance. Second, it is less robust to unforeseen events than an earnings-based plan. Third, it has different pay-for-performance sensitivity across periods even if the underlying production function remains unchanged. In contrast, if earnings match delivered performance, ${ }^{2}$ an earnings-based plan requires less information in its design and is robust and stationary, as shown below.

Consider a two-period setting. In the first period the market learns that a firm has a new project that will be implemented in period 2. Since performance is delivered (i.e., project is implemented), only in period 2, earnings in period 1 are zero. Earnings in period 2, $A_{2}$, will depend on the manager's effort and ability to implement the project and noise. Price at the end of period $1, \mathrm{P}_{1}$, will reflect the expectations of the net present value of the project.

Let us focus on the price-based performance measure for period 2, which is the change in price or $\Delta \mathrm{P}_{2}=\mathrm{P}_{2}-\mathrm{P}_{1}$. Both $\mathrm{A}_{2}$ and $\Delta \mathrm{P}_{2}$ are equally informative about the manager's performance in period 2 in the sense that both respond to the project's outcome in period 2. It appears that the firm could use either performance measure in a one-period contract covering period 2. The discussion below, however, exposes the weaknesses of a price-based plan.

Consider a manager who was expected to do very well and does slightly better than expected. Although $\Delta \mathrm{P}_{2}$ will be small positive, the manager should be rewarded highly for performing very well by absolute standards. So, contingent upon the knowledge that the market expected the manager to do well, the pay sensitivity must be high (a large reward for a small

\footnotetext{
${ }^{2}$ The extent to which earnings match delivered performance depends on the setting. Generally Accepted Accounting Principles (GAAP) require that revenues be recorded only after they have been earned and realizable. Earnings will therefore be matched with delivered performance for selling activities, but earnings will lag delivered performance for $R \& D$ because current successful $R \& D$ (delivered performance) produces future cash flows that are difficult to verify. In these settings, adjusted earnings, such as economic value added, are used. The adjusted earnings, however, rarely include expectations of performance not yet delivered.
} 
performance measure, $\Delta \mathrm{P}_{2}$ ). Now suppose the manager performs slightly below the expected level. The price change will be small negative. In this case, the pay sensitivity must be negative (a reward for a small negative price change). Now consider a manager who was expected to have mediocre performance but does slightly better than expected. The price increase will be small, but the compensation is also expected to be quite small.

The example above shows that at the beginning of each period the pay-for-performance sensitivity of the stock-based contract will have to be adjusted to reflect current market expectations. If board members have incomplete information about market expectations, which they surely do, then this period-by-period adjustment of the stock-based compensation contract will be difficult if not impossible. In contrast, earnings-based plans are unaffected by the extent to which prices anticipate earnings. We argue that instead of trying to infer delivered performance from price changes the board of directors would find it more efficient to rely on accountants to make earnings match delivered performance by using their knowledge of underlying transactions.

Price-based contracts are less robust to unforeseen events than earnings-based contracts. Price-based contracts need recalibration due to unforeseen events that affect the current period performance as well as expected future performance. Earnings-based contracts are less likely to be affected by unforeseen events that affect expected future performance.

Price-based contracts require changes in pay-performance sensitivity across time even if the underlying production function is stationary. If a manager works on a project that has identical tasks across time, the pay-performance sensitivity of a price-based contract may have to be lower earlier and higher later. This is because if in period 1 the market anticipates much of the future delivered performance, the price change in period 1 will be larger than the price change in future periods. Earnings, in contrast, will rise only when the performance is delivered, so an earnings-based contract will be simpler in that it can have the same pay sensitivity across time. We capture this feature by comparing performance measures while keeping the production function and the compensation plan stationary over time. This distinguishes our model from earlier research.

We predict that because of these contracting costs the relative use of stock-price changes and earnings as performance measures will increase with each measure's contemporaneous 
correlation with delivered performance. The continued popularity of earnings-based plans suggests that their matching to delivered performance outweighs their imperfections. Although we analyze compensation plans, our predictions apply to all settings where measures of delivered performance are required.

An important implication of our analysis is that the contemporaneous correlation between earnings and stock price changes is not the correct yardstick to evaluate alternative accounting standards. The very fact that accounting numbers exclude expectations of future delivery of performance makes these numbers useful in contracts even if it lowers contemporaneous correlation with price changes. This differs from the traditional view of conservatism, which states that accountants exclude subjective future expectations to avoid earnings manipulation.

Section 2 presents a detailed example to illustrate the intuition underlying our results. Section 3 presents the model, section 4 presents analysis and results, and section 5 concludes the paper.

\section{A Comparison of Three Tasks}

In this section we use an example to illustrate the basic argument and the model. In the example a manager must be motivated to perform three tasks over three periods: (1) win a contract for a construction project, (2) minimize costs while meeting project specifications, and (3) collect cash from the customer. Since measuring delivered performance on the second task is the main point of our paper, we discuss it first in section 2.1. Sections 2.2 and 2.3 discuss measurement of delivered performance related to tasks 1 and 3 respectively. Section 2.4 discusses the practical constraints that limit contract duration and shows that compensation contracts are less costly to shareholders if they are based on measures of delivered performance. Section 2.5 discusses how the contemporaneous correlation of performance measures with delivered performance affects their use in compensation contracts and the general inseparability between performance measures and compensation functions.

\subsection{Providing incentives to control costs}

In this section we isolate delivered performance related to controlling costs while meeting project specifications by assuming that winning the contract and collecting cash from the customers requires no managerial effort. 
Suppose near the end of year 1, a publicly-traded firm gets a contract to build a road for the government. Suppose the firm has unique expertise to build the road and so winning the contract requires no effort. To simplify the exposition we assume that the announcement that the firm has won the contract is a surprise to the market. Section 2.2 relaxes this assumption. The firm expects to build the road in year 2 and be paid in year 3. Completion of the project within the allotted time and budget requires sustained managerial effort in year 2 and conditional on high managerial effort, the contract is a positive NPV project for the firm. The government is unlikely to default, so collecting the cash requires no managerial effort.

\section{-- insert figure 1 about here -}

Figure 1A shows that there will be no cash flow from the project in year 1, there will be a negative cash flow in year 2 (when the firm pays its suppliers and employees for work on the project), which could be $-\$ 65$ if the costs are in control, or $-\$ 75$ if there are cost overruns. The probability of a cost overrun depends on the manager's effort. There will be a positive cash flow in year 3 of $\$ 100$ when the firm is paid.

Figure 1B shows that most of the stock-price movement will occur in year 1 when the contract is announced. For simplicity, assume a zero discount rate and assume that the probability of a cost overrun if the manager works hard is 0.5 . The price increase in year 1 is the expected NPV of the project. If the market expects the manager to work hard in year 2, then the expected price increase in year 1 is $\$ 100-\left(0.5^{*} 65+0.5^{* 75}\right)=\$ 30$. If the manager is able to control the costs effectively in year 2 , then the price will rise by an additional $\$ 5$, otherwise it will fall by $\$ 5$. In year 3 there will be no price movement because payment by the government is fully anticipated.

Figure 1C shows how accountants will record earnings based on the concepts of periodicity, recognition, matching, and conservatism. Earnings, defined as revenues minus expenses, are a periodic performance measure. Accountants do not define revenues to be simply equal to the cash receipts in a period. Rather they exclude cash received from prior-period sales and include only those expected future cash collections that are due to the selling activity in the current period. Thus revenue is recognized before cash is received if the revenue is "earned" (by delivering goods to the customer) and "realized" (by obtaining a reasonable assurance of payment). Accountants in our road construction example will book no revenue or expense in 
year 1. If the project meets specifications at the end of year 2 and there is sufficient assurance that cash would be received in year 3, then accountants would book revenue in year 2 even if no cash is received. Similarly, expenses are not simply cash outflows; rather they reflect the matching cost of resources consumed in generating current period revenues. If some cash outflows in year 2 were to purchase machinery that would be used in other projects, then these cash outflows would not be immediately expensed, but would be capitalized and expensed when the machinery is used on other projects. Thus accounting earnings are neither equal to net cash flows nor are they equal to change in market value.

The three signals - price changes, cash flows, and earnings are equally informative about the outcome of the manager's effort in year 2. Earnings, however, are matched to the delivered performance, while cash flows and price changes are not.

As shown in figure 1A, cash flows are poorly matched with the delivery of managerial performance. They are negative in year 2 when effort is required and positive in year 3 when no effort is required. Cash flows are often tempting candidates as performance measures because they are easily understood and because auditing them does not require much judgment, which reduces ex-post reporting discretion and manipulation. However, they suffer from poor matching and possible manipulation through trivial changes in the form and timing of payment. For example, managers can delay payments to suppliers, or refuse to sell on credit.

As shown in figure $1 \mathrm{~b}$, if the managers' work in year 2 is largely anticipated when the firm wins the contract, then stock-price changes are also poorly matched with the value added by managers with respect to completing the project within time and budget.

In our stylized example, which we think captures important aspects of reality, earnings are the superior performance measure. This is true in spite of the fact that the association between earnings and stock-price changes is low. To the contrary, it is the earnings' ability to provide an independent measure of delivered performance that makes them useful in this context.

\subsection{Providing incentives to win the contract}

In this section we analyze which performance measure is contemporaneous with delivered performance related to winning the contract. To isolate this task, in this section we assume that completing the project and collecting cash from the customers requires no managerial effort. 
The effort required to win the contract is expended in year 1. Cash flows are obviously not contemporaneous with managers' work. Accountants will book no earnings when the contract is announced because they cannot verify the value added when managers win the contract. Conservatism causes earnings to be a poor measure of delivered performance in situations where managers have delivered performance, but accountants book no earnings because there is insufficient evidence of future cash flows.

If a CEO primarily identifies new investment opportunities, then earnings will be a poor measure of performance. For projects with long payback periods, such as research and development (R\&D), there is little evidence of future cash flows in the early stages of the project. Instead of relying on managerial estimates of future profitability of R\&D projects, accountants expense all R\&D costs and book no revenues, which makes earnings lag delivered performance. On the flip side, earnings can lead delivered performance if accountants fail to record all expenses such as the cost of post-retirement health benefits.

The contemporaneous correlation between stock price changes and value added by managers in winning the contract depends inversely on two factors: (1) the degree to which the award of the contract is anticipated, and (2) the extent to which winning the contract causes revisions of expectations of future performance. If winning the contract is a complete surprise, and it does not lead to expectations that managers will exert effort in subsequent periods to complete the contract and win other contracts, then as shown in figure 1 stock price changes match value added by managers in winning the contract. The more the market anticipates the manager's actions, the more stock prices will lead delivered performance, and consequently, the less useful stock prices will be as a performance measure. One can argue that for highly unpredictable activities such as research and development, price changes are contemporaneous with delivered performance.

\subsection{Providing incentives to collect cash}

Until now we have assumed that collecting cash requires no effort and is not uncertain. There are situations such as installment sales where this is not true. If cash collection is quite uncertain and requires effort, then accountants use the installment method, which recognizes earnings as cash is collected. If the uncertainty about cash collection is less, then accountants use the allowance method, which defers part of the earnings until the uncertainty about cash 
collection is resolved. This makes earnings capture the delivery of performance related to cash collection. Of course, if accountants' judgment is misplaced, then earnings will not reflect the effort required to collect cash, which may prompt the use of cash flows as a performance measure. If cash collection is largely unpredictable, then stock price changes will also be contemporaneous with the effort required to collect cash, otherwise they suffer from the usual problem of anticipating cash collection.

We now turn to the discussion of why compensation contracts are less costly to shareholders if they are based on measures of delivered performance.

\subsection{The Constraints That Limit Contract Duration}

The desire to pay managers for delivered performance is driven by the usual agency conflict between shareholders and managers, and by the following two practical constraints that limit contract duration.

\section{Constraint 1: It is Costly to Recover Previously Paid Compensation.}

There are legal and practical limits on the amount of compensation that can be recovered from managers if they fail to perform according to expectations. Compensation can be deferred using long-term bonus plans or nonvested stock or option grants. But once compensation is paid, it generally is not taken back. The inability to recover previously paid compensation implies that firms would not pay managers before they have worked because up-front payments without expost settlements provide no incentives.

Constraint 2: It is Costly to Withhold Compensation for Extended Periods.

If firms write long-term contracts, i.e., they wait long enough to pay their managers, then the performance measures that differ only in their timing converge. However, managers' risk aversion, their desire to smooth consumption, and the difficulty of enforcing long-term contracts, generate a demand for periodic payments from the firm. Withholding compensation after managers have worked is costly to firms because managers demand higher compensation. Since it is not unusual for firms to engage in projects that require sustained managerial effort over many years, firms usually contract with and pay managers over horizons that are short in relation to the life of their investment projects.

The combined effect of these constraints is that firms will not pay managers before they have worked, nor will they withhold compensation for long after managers have worked. Instead, 
firms will seek performance measures that allow them to evaluate and pay managers periodically for their delivered performance. [See Dye (1985) for a discussion of the optimal length of labor contracts.]

\subsection{Modify compensation functions or use measures of delivered performance?}

A manager's pay is the joint result of the performance measure and the compensation function that is used to map the performance measure to his pay. In general, it is difficult to separate the effect of performance measures and compensation functions. Before we discuss this issue further it is useful to define stationary compensation functions.

Stationary compensation function: A stationary compensation function is a mapping from a performance measure to the manager's compensation such that if the realization of the performance measure is the same in any two periods, then the manager's compensation is also the same in the two periods. Thus our definition implies that the same compensation function is used in each period.

A firm can pay its managers for delivered performance in two ways: (1) use a stationary compensation function based on a measure that is matched with delivered performance, or (2) use a performance measure that is not matched with delivered performance, but is informative about it, and modify the compensation function each period (i.e., use a non-stationary function) so that managers are paid for delivered performance. Let us examine these two alternatives in the road construction setting where the firm wants to motivate its managers to control costs in year 2 and the managers need to be paid annually. (The length of the period here is arbitrary. The basic issues are relevant as long as the contract duration is shorter than the life of the project.)

Since the manager is expected to exert effort to control costs only in year 2, and since advance payments provide no incentives, any bonus paid to the manager at the end of year 1 is an excess payment. Regardless of this bonus paid at the end of year 1, the manager would again need to be motivated with incentive payments at the end of year 2. Thus under the optimal contract the manager would receive an incentive pay at the end of year 2 and would receive no incentive pay at the end of years 1 and 3. To provide the manager with the incentives to control costs in year 2, the compensation plan must pay the manager higher compensation when costs are low in year two than when they are high. Let us examine how earnings as well as price changes can be used to reward the managers for delivered performance in this setting. 
Earnings are recorded only in year 2 and are higher if the costs are lower and vice versa. So a stationary compensation function based on earnings would pay the manager for controlling costs in year 2 and would provide no incentive pay in years 1 or 3 . In year 1 stock prices increase by $\$ 30$ and in year 2 they increase by only $\$ 5$ if costs are controlled, and decrease by $\$ 5$ if there are cost overruns. Therefore, a stationary compensation plan that provides the required incentive payments at the end of year 2, will also provide a larger incentive pay at the end of year 1, which is unnecessary. To avoid the excess payment at the end of year 1, a price-based compensation function will have to be non-stationary. It will have zero sensitivity of pay to price changes in year 1, and a positive sensitivity of pay to price changes in year 2 .

In general, such modification of compensation function each period amounts to the firm

doing the compensation design in two steps: (1) based on the knowledge of underlying transactions, modify a given performance measure to yield a measure of delivered performance, and (2) use a stationary compensation function based on the modified performance measure. The firm need not perform step 1 if they use a measure of delivered performance, e.g., earnings in the road construction example.

If a measure that is contemporaneous with delivered performance is available, then firms will prefer stationary functions based on the measure as compared to another measure that requires adjustments to make it contemporaneous with delivered performance (or requires nonstationary functions). We note that firms typically do not make dramatic period-by-period changes to their managers' pay-for-performance sensitivity. In cases where the accrual process results in measures of delivered performance, firms use stationary functions based on earnings.

To test whether a firm can use cash flows, earnings, and price changes in a given setting without modifying compensation functions each period, we will study the use of these measures in conjunction with stationary compensation functions.

\section{Model}

We analyze a setting where the board of directors must choose a performance measureaccounting earnings, change in market value, or net cash flows-on which to base senior managers' compensation. For the analysis in this paper, it is sufficient to model the contract between one principal and one agent. The principal cannot observe the agent's effort. 
Section 3.1 describes the sequence of events. Section 3.2 describes the degree of commitment assumed in the model, borrowing and lending opportunities available to the agent, and the utility functions. Section 3.3 defines the principal's problem if general compensation functions (defined below) are allowed. Section 3.4 defines "price-based," "cash-based," and "earnings-based" compensation contracts.

\subsection{Sequence of Events}

-- insert figure 2 about here-

Figure 2 outlines the sequence of events. At time $t_{0}$, the firm's market value is $\mathrm{P}_{0}$. At time $\mathrm{t}_{0}+\varepsilon$, the agent announces a new investment opportunity that requires an immediate cash outlay of K. The investment opportunity available to the agent is fixed. The announcement of this project is a surprise to the market, so $\mathrm{P}_{0}$ does not include expectations of cash flows from the project. $^{3}$

In period 1, the agent expends effort $\mathrm{a}_{1} \varepsilon\left[\mathrm{a}_{\mathrm{L}}, \mathrm{a}_{\mathrm{H}}\right]$ to execute the project. We assume that $a_{H}$ has higher disutility to the agent than $a_{L}\left(a_{H}>a_{L}\right)$, and that the principal prefers $a_{H}$. The cash flow at the end of period 1 (before the agent is paid) could be either $\mathrm{C}_{\mathrm{S} 1}$ (if the project succeeds) or $\mathrm{C}_{\mathrm{F} 1}$ (if the project fails) where $\mathrm{C}_{\mathrm{S} 1}>\mathrm{C}_{\mathrm{F} 1}$. If $\mathrm{a}_{1}=\mathrm{a}_{\mathrm{H}}$, then the probability of realizing $\mathrm{C}_{\mathrm{S} 1}$ is $\mathrm{q}_{\mathrm{H}}$, otherwise it is $\mathrm{q}_{\mathrm{L}},\left[\mathrm{q}_{\mathrm{H}}>\mathrm{q}_{\mathrm{L}}>0\right]$. The agent is paid $\mathrm{W}_{\mathrm{S} 1}$ if the project succeeds, otherwise he is paid $\mathrm{W}_{\mathrm{F} 1}$.

If the project fails in period 1 it is terminated. If the project succeeds in period 1 , it is continued in period 2 (without additional investment) where the agent (there could be a different agent in period 2) takes action $\mathrm{a}_{2} \varepsilon\left[\mathrm{a}_{\mathrm{L}}, \mathrm{a}_{\mathrm{H}}\right]{ }^{4}$ The principal again prefers $\mathrm{a}_{\mathrm{H}}$. The cash flow at the end of period 2 (before the agent is paid) could be $\mathrm{C}_{\mathrm{S} 2}$ or $\mathrm{C}_{\mathrm{F} 2}, \mathrm{C}_{\mathrm{S} 2}>\mathrm{C}_{\mathrm{F} 2}$. If $\mathrm{a}_{2}=\mathrm{a}_{\mathrm{H}}$, then the probability of realizing $\mathrm{C}_{\mathrm{S} 2}$ is $\mathrm{q}_{\mathrm{H}}$, otherwise it is $\mathrm{q}_{\mathrm{L}},\left[\mathrm{q}_{\mathrm{H}}>\mathrm{q}_{\mathrm{L}}>0\right]$. The agent is paid $\mathrm{W}_{\mathrm{S} 2}$ if the project succeeds, otherwise he is paid $\mathrm{W}_{\mathrm{F} 2}$. The project terminates at the end of period 2.

\footnotetext{
${ }^{3}$ If the project were anticipated, the delivered versus expected performance problem remains but is shifted to earlier periods. We discuss this further in section 4.2.

${ }^{4}$ We do not model the effect of revision of beliefs about the manager's skill, or the acquisition of firm specific skills by the manager [Holmstrom and Costa (1986)].
} 


\subsection{Commitment, Access to Capital Markets, and Utility Functions}

The extensive literature on multiperiod contracts [see Chiappori et al. (1994) for a summary] shows that the results are sensitive to the specific assumptions. Before proceeding to the results, we describe how our assumptions are different from those underlying other models and explain the implications of these differences.

Commitment: We want to focus on whether earnings, cash flows, or the change in market value is better matched with delivered performance, and whether this matching allows more efficient contracts. Choice among the three performance measures is moot for long-term contracts since these performance measures converge in the long run. However, practical considerations dictate that firms write shorter-term contracts. For example, multiperiod commitment by the agent is often not legally enforceable. We assume that both the principal and the agent can commit for only one period. The paper's intuition holds even if the principal can commit for longer periods, which is not uncommon. We assume a one-period commitment for simplicity and because it provides a setting that highlights the effect of timing differences between cash flows, earnings, and price changes vis-à-vis delivery of performance.

If both principal and agent can credibly commit over a project's life [Lambert (1983), Rogerson (1985)] or if only the principal can commit and the agent cannot borrow or lend [Lambert (1983)], then contracts exhibit "memory" and "smoothing." These effects are diminished if the agent can borrow or lend because the principal need not act as a "bank" [Fudenberg, Holmstrom, and Milgrom (1990)]. Since we assume one-period contracts, we do not analyze issues of consumption smoothing and memory in contracts.

Access to capital markets: We assume that the agent can borrow and lend in the capital market, so he is indifferent whether the principal, acting as a bank, smoothes his compensation. To avoid complexities due to trivial transfers of compensation from period 1 to 2 , we assume that any compensation promised to the agent in a period is paid to him in the same period.

Utility functions: The principal is risk-neutral and her utility is additive across periods with a zero discount rate, i.e., she maximizes the sum of expected profits over the two periods. In our two-period model, the issues associated with assuming a zero discount rate are not important. For a discussion see Rubinstein and Yaari (1983) and Radner (1985). 
The agent is risk-averse and his utility is additively separable in wealth and effort. His utility of wealth is denoted by $\mathrm{U}$ [U' $>0$ and $\mathrm{U}^{\prime}$ ' $<0$ everywhere] and his reservation utility is denoted by R. The agent's disutility of effort is denoted by D [D'>0 and D' > 0 everywhere]. U and $\mathrm{D}$ are assumed to be additively separable by periods and for simplicity are assumed to be the same for all periods. Since we assume period-by-period contracting, we need not add agent's utility across periods. The contracts for two periods could be different even if the utility functions are the same if the agent accumulates wealth in the first period. So we assume that either the agent has constant absolute risk aversion or consumes all of the compensation received in the first period.

\subsection{The Principal's Problem if General Compensation Functions Are Allowed}

We first discuss what the principal would do if there were no constraints on the form of compensation functions. We label such functions as general compensation functions or generalized contracts. In subsequent sections we discuss more realistic settings where the principal uses cash-based, earnings-based, or price-based compensation functions that are not general functions.

Since we assume that the principal wants to induce $\mathrm{a}_{\mathrm{H}}$ in both periods, her problem can be stated as:

$\operatorname{Max}\left[\mathrm{q}_{\mathrm{H}}\left(\mathrm{C}_{\mathrm{S} 1}-\mathrm{W}_{\mathrm{S} 1}\right)+\left(1-\mathrm{q}_{\mathrm{H}}\right)\left(\mathrm{C}_{\mathrm{F} 1}-\mathrm{W}_{\mathrm{F} 1}\right)\right]+\mathrm{q}_{\mathrm{H}}\left[\mathrm{q}_{\mathrm{H}}\left(\mathrm{C}_{\mathrm{S} 2}-\mathrm{W}_{\mathrm{S} 2}\right)+\left(1-\mathrm{q}_{\mathrm{H}}\right)\left(\mathrm{C}_{\mathrm{F} 2}-\mathrm{W}_{\mathrm{F} 2}\right)\right]-\mathrm{K}$

$\left(\mathrm{W}_{\mathrm{S} 1}, \mathrm{~W}_{\mathrm{S} 2}, \mathrm{~W}_{\mathrm{F} 1}, \mathrm{~W}_{\mathrm{F} 2}\right)$

such that

$\mathrm{q}_{\mathrm{H}} \mathrm{U}\left(\mathrm{W}_{\mathrm{S} 1}\right)+\left(1-\mathrm{q}_{\mathrm{H}}\right) \mathrm{U}\left(\mathrm{W}_{\mathrm{F} 1}\right)-\mathrm{D}\left(\mathrm{a}_{\mathrm{H}}\right) \geq \mathrm{R}$

$\mathrm{q}_{\mathrm{H}} \mathrm{U}\left(\mathrm{W}_{\mathrm{S} 2}\right)+\left(1-\mathrm{q}_{\mathrm{H}}\right) \mathrm{U}\left(\mathrm{W}_{\mathrm{F} 2}\right)-\mathrm{D}\left(\mathrm{a}_{\mathrm{H}}\right) \geq \mathrm{R}$

$\mathrm{q}_{\mathrm{H}} \mathrm{U}\left(\mathrm{W}_{\mathrm{S} 1}\right)+\left(1-\mathrm{q}_{\mathrm{H}}\right) \mathrm{U}\left(\mathrm{W}_{\mathrm{F} 1}\right)-\mathrm{D}\left(\mathrm{a}_{\mathrm{H}}\right) \geq \mathrm{q}_{\mathrm{L}} \mathrm{U}\left(\mathrm{W}_{\mathrm{S} 1}\right)+\left(1-\mathrm{q}_{\mathrm{L}}\right) \mathrm{U}\left(\mathrm{W}_{\mathrm{F} 1}\right)-\mathrm{D}\left(\mathrm{a}_{\mathrm{L}}\right)$

$\mathrm{q}_{\mathrm{H}} \mathrm{U}\left(\mathrm{W}_{\mathrm{S} 2}\right)+\left(1-\mathrm{q}_{\mathrm{H}}\right) \mathrm{U}\left(\mathrm{W}_{\mathrm{F} 2}\right)-\mathrm{D}\left(\mathrm{a}_{\mathrm{H}}\right) \geq \mathrm{q}_{\mathrm{L}} \mathrm{U}\left(\mathrm{W}_{\mathrm{S} 2}\right)+\left(1-\mathrm{q}_{\mathrm{L}}\right) \mathrm{U}\left(\mathrm{W}_{\mathrm{F} 2}\right)-\mathrm{D}\left(\mathrm{a}_{\mathrm{L}}\right)$

It is well known that, for a risk-averse agent both IR (individual rationality or participation) constraints and IC (incentive compatibility) constraints are binding at the optimum. We assume that the principal strictly prefers that the agent undertake the project in period 1 and weakly prefers that if successful, the project be continued into period 2 . This is captured by the two PR (principal's rationality) constraints stated below:

$\mathrm{q}_{\mathrm{H}}\left(\mathrm{C}_{\mathrm{S} 1}-\mathrm{W}_{\mathrm{S} 1}\right)+\left(1-\mathrm{q}_{\mathrm{H}}\right)\left(\mathrm{C}_{\mathrm{F} 1}-\mathrm{W}_{\mathrm{F} 1}\right)+\mathrm{q}_{\mathrm{H}}\left(\mathrm{q}_{\mathrm{H}}\left(\mathrm{C}_{\mathrm{S} 2}-\mathrm{W}_{\mathrm{S} 2}\right)+\left(1-\mathrm{q}_{\mathrm{H}}\right)\left(\mathrm{C}_{\mathrm{F} 2}-\mathrm{W}_{\mathrm{F} 2}\right)\right)-\mathrm{K}>0$ 
$\mathrm{q}_{\mathrm{H}}\left(\mathrm{C}_{\mathrm{S} 2}-\mathrm{W}_{\mathrm{S} 2}\right)+\left(1-\mathrm{q}_{\mathrm{H}}\right)\left(\mathrm{C}_{\mathrm{F} 2}-\mathrm{W}_{\mathrm{F} 2}\right) \geq 0$

(PR2)

We allow the compensation function to have quite general functional forms. As illustrated in figure 4, we do not rule out floors and/or ceilings on compensation. (The monotonelikelihood-ratio-property (MLRP) holds in our model.) To rule out trivial flat wage contracts, we assume that compensation is increasing in the performance measure over at least some range.

-- insert figure 3 about here -

We assume that the expected cash flows from the project are high enough so that the principal's rationality constraints (PR1 and PR2) are satisfied under a generalized contract. It can be shown that that the optimal contract would make $\mathrm{W}_{\mathrm{S} 1}=\mathrm{W}_{\mathrm{S} 2}=\mathrm{W}_{\mathrm{S}}, \mathrm{W}_{\mathrm{F} 1}=\mathrm{W}_{\mathrm{F} 2}=\mathrm{W}_{\mathrm{F}}$, and $\mathrm{W}_{\mathrm{S}}$ $>\mathrm{W}_{\mathrm{F}}$. This is because the agent is to be induced to work equally hard in both periods. We focus on only the requirements that $\mathrm{W}_{\mathrm{S} 1}=\mathrm{W}_{\mathrm{S} 2}=\mathrm{W}_{\mathrm{S}}$ and $\mathrm{W}_{\mathrm{S}}>\mathrm{W}_{\mathrm{F}}$, because $\mathrm{W}_{\mathrm{F} 1}=\mathrm{W}_{\mathrm{F} 2}=\mathrm{W}_{\mathrm{F}}$ can be

trivially satisfied by assuming that in case the project fails, the compensation hits a floor in both periods.

A case where the compensation hits the ceiling in both periods is uninteresting and unrealistic. This is because once the compensation hits a ceiling, differences in earnings, cash flows, and price changes would have no effect on the compensation. Accordingly, we assume that the compensation does not hit the ceiling in at least one period.

\subsection{Defining "cash-based," "earnings-based," and "price-based" plans}

The remainder of the paper examines the conditions under which a stationary compensation function based on cash flows, earnings, and stock prices can mimic an incentive pay scheme that is optimal under a generalized contract. We operationalize stationary cash-flowbased, earnings-based, and price change-based plans in the context of our model below. These definitions form the basis of analysis in section 4. For brevity, we omit the word "stationary" when discussing compensation plans.

Cash Flow-Based Plan: In our model, we focus on net cash flows from operations and investments, and exclude financing related cash flows. Thus, net-cash-flow-based compensation implies ( $f_{\mathrm{C}}$ denotes the stationary cash-flow-based compensation function)

$$
\mathrm{W}_{\mathrm{S} 1}=\mathrm{f}_{\mathrm{C}}\left(\mathrm{C}_{\mathrm{S} 1}-\mathrm{K}\right), \mathrm{W}_{\mathrm{S} 2}=\mathrm{f}_{\mathrm{C}}\left(\mathrm{C}_{\mathrm{S} 2}\right), \mathrm{W}_{\mathrm{F} 1}=\mathrm{f}_{\mathrm{C}}\left(\mathrm{C}_{\mathrm{F} 1}-\mathrm{K}\right), \mathrm{W}_{\mathrm{F} 2}=\mathrm{f}_{\mathrm{C}}\left(\mathrm{C}_{\mathrm{F} 2}\right)
$$

Earnings-Based Plan: Accountants do not expense the entire expenditure $\mathrm{K}$ on the project in the first period. We assume that a fraction $\delta$ is expensed in period 1 and fraction $(1-\delta)$ is expensed 
in period 2. ${ }^{5}$ We later discuss the situations under which this is an accurate description of the accrual process and also how computation of $\delta$ affects the compensation plans. Thus earningsbased compensation implies

$$
\begin{aligned}
& \mathrm{W}_{\mathrm{S} 1}=\mathrm{f}_{\mathrm{E}}\left(\mathrm{E}_{\mathrm{S} 1}\right), \mathrm{W}_{\mathrm{S} 2}=\mathrm{f}_{\mathrm{E}}\left(\mathrm{E}_{\mathrm{S} 2}\right), \mathrm{W}_{\mathrm{F} 1}=\mathrm{f}_{\mathrm{E}}\left(\mathrm{E}_{\mathrm{F} 1}\right), \mathrm{W}_{\mathrm{F} 2}=\mathrm{f}_{\mathrm{E}}\left(\mathrm{E}_{\mathrm{F} 2}\right) \text { where } \\
& \mathrm{E}_{\mathrm{S} 1}=\mathrm{C}_{\mathrm{S} 1}-\delta \mathrm{K}, \mathrm{E}_{\mathrm{F} 1}=\mathrm{C}_{\mathrm{F} 1}-\delta \mathrm{K}, \mathrm{E}_{\mathrm{S} 2}=\mathrm{C}_{\mathrm{S} 2}-(1-\delta) \mathrm{K}, \mathrm{E}_{\mathrm{F} 2}=\mathrm{C}_{\mathrm{F} 2}-(1-\delta) \mathrm{K} .
\end{aligned}
$$

Price Change-Based Plan: Since the firm has no debt, the market value of the firm and the market value of equity are synonymous in our model. It is easy to see that a price-change-based compensation implies

$$
\mathrm{W}_{\mathrm{S} 1}=\mathrm{f}_{\mathrm{P}}\left(\mathrm{P}_{\mathrm{S} 1}-\mathrm{P}_{0}\right), \mathrm{W}_{\mathrm{S} 2}=\mathrm{f}_{\mathrm{P}}\left(\mathrm{P}_{\mathrm{S} 2}-\mathrm{P}_{\mathrm{S} 1}\right), \mathrm{W}_{\mathrm{F} 1}=\mathrm{f}_{\mathrm{P}}\left(\mathrm{P}_{\mathrm{F} 1}-\mathrm{P}_{0}\right), \mathrm{W}_{\mathrm{F} 2}=\mathrm{f}_{\mathrm{P}}\left(\mathrm{P}_{\mathrm{F} 2}-\mathrm{P}_{\mathrm{S} 1}\right)
$$

\section{Analysis and Results}

In section 4.1 we specify the conditions under which an optimal payment plan can be implemented by a stationary compensation plan based on cash flows, earnings, or change in firm's market value. The analysis is performed under two settings. Section 4.2 assumes that the project requires no investment (i.e., $\mathrm{K}=0$ ) so that there is no difference between cash flows and earnings. Our analysis shows that, since prices anticipate delivered performance, a price-based plan overpays the agent, but not an earnings-based plan. Section 4.3 is more realistic in that investment $\mathrm{K}$ is positive. The main result is that, like a price-based plan, a cash-based plan will also overpay the agent whereas an earnings-based plan will not. This result is obtained because accountants depreciate only a part of the cost of investment in period 1 . The insight from this result is that it is sensible to depreciate an investment only partially even if the costs are sunk.

We use the extent of overpayment to the manager as the criterion to evaluate alternative compensation plans. One could argue that in an agency setting it is not so much the manager's compensation, but the manager's actions that are of concern. However, in agency-theoretic models, a principal can induce an agent to take whatever action the principal wants. Therefore, it is the cost of inducing these actions that leads the principal to induce one action over another. So

\footnotetext{
${ }^{5}$ Alternatively, the entire investment $\mathrm{K}$ can be expensed in period 1 if the project fails. Our results are not sensitive to this assumption because we allow floors on compensation to be hit in both periods. This can also be dealt with by assuming that depreciation and loss from discontinued operations are disclosed separately and the manager is evaluated on the basis of operating income. The ability to separate earnings into those under managerial control and those beyond managerial control may enhance the usefulness of earnings as a performance measure. However, in general, such separation is difficult.
} 
in general, in a second-best contract, the optimal action to be induced and the payment to the agent could both be different from the first-best setting. For ease of exposition, we have chosen to fix the action - the principal always wants the agent to take $a_{H}$, but the cost of inducing the action depends on the compensation plan chosen.

\subsection{When can cash-based, earnings-based, or price-based plans mimic the optimal plan}

Cash-based plan: The generalized contract solution requires that $\mathrm{W}_{\mathrm{S} 1}=\mathrm{W}_{\mathrm{S} 2}=\mathrm{W}_{\mathrm{S}}$. Thus, a cashbased compensation plan will be optimal (in the sense that it will induce the desired managerial action at the same cost as the generalized contract) if and only if $\mathrm{W}_{\mathrm{S} 1}=\mathrm{f}_{\mathrm{C}}\left(\mathrm{C}_{\mathrm{S} 1}-\mathrm{K}\right)=\mathrm{W}_{\mathrm{S} 2}=$ $\mathrm{f}_{\mathrm{C}}\left(\mathrm{C}_{\mathrm{S} 2}\right)$. Since we do not allow the compensation to hit the ceiling in both periods, the previous condition implies the following Optimality Condition for Cash (OCC): ${ }^{6}$

$$
\mathrm{C}_{\mathrm{S} 1}-\mathrm{K}=\mathrm{C}_{\mathrm{S} 2} \text {. }
$$

$\mathrm{W}_{\mathrm{S}}>\mathrm{W}_{\mathrm{F}}$ is feasible under a cash-flow-based compensation plan if and only if $\mathrm{C}_{\mathrm{S} 2}$ (which must be equal to $\mathrm{C}_{\mathrm{S} 1}-\mathrm{K}$ ) is greater than minimum of $\mathrm{C}_{\mathrm{F} 1}$ and $\mathrm{C}_{\mathrm{F} 2}$. In addition, the principal's rationality constraints (PR1 and PR2) must be satisfied. That is, a cash-based plan will implement the optimal solution under only a small set of parameter values.

Earnings-based plan: An earnings-based compensation plan will be optimal if and only if $\mathrm{W}_{\mathrm{S} 1}$ $=\mathrm{f}_{\mathrm{E}}\left(\mathrm{C}_{\mathrm{S} 1}-\delta \mathrm{K}\right)=\mathrm{W}_{\mathrm{S} 2}=\mathrm{f}_{\mathrm{E}}\left(\mathrm{C}_{\mathrm{S} 2}-(1-\delta) \mathrm{K}\right)$, i.e., $\mathrm{C}_{\mathrm{S} 1}-\delta \mathrm{K}=\mathrm{C}_{\mathrm{S} 2}-(1-\delta) \mathrm{K}$, i.e., the following Optimality Condition for Earnings (OCE) is satisfied:

$$
\delta=\left(\mathrm{K}+\mathrm{C}_{\mathrm{S} 1}-\mathrm{C}_{\mathrm{S} 2}\right) / 2 \mathrm{~K} .
$$

In addition, the principal's rationality constraints (PR1 and PR2) must also be satisfied. That is, by properly choosing the depreciation factor $\delta$, an earnings-based plan can implement the optimal solution under a wide range of parameters.

Price-based plan: As shown in the appendix, a price-based compensation plan will be optimal if and only if the following $\underline{\text { Optimality }}$ Condition for Price (OCP) is satisfied:

$$
2\left[\mathrm{q}\left(\mathrm{C}_{\mathrm{S} 2}-\mathrm{W}_{\mathrm{S} 2}\right)+(1-\mathrm{q})\left(\mathrm{C}_{\mathrm{F} 2}-\mathrm{W}_{\mathrm{F} 2}\right)\right]+\left(\mathrm{C}_{\mathrm{S} 1}-\mathrm{C}_{\mathrm{S} 2}\right)-\mathrm{K}=0 \text {. }
$$

\footnotetext{
${ }^{6}$ In our model, it would be possible to set $\mathrm{f}_{\mathrm{C}}\left(\mathrm{C}_{\mathrm{S} 1}-\mathrm{K}\right)=\mathrm{f}_{\mathrm{C}}\left(\mathrm{C}_{\mathrm{S} 2}\right)$ by defining the ceiling on compensation equal to min( $\left.\mathrm{f}_{\mathrm{C}}\left(\mathrm{C}_{\mathrm{S} 1}-\mathrm{K}\right), \mathrm{f}_{\mathrm{C}}\left(\mathrm{C}_{\mathrm{S} 2}\right)\right)$. This results in an uninteresting case where the ceiling is hit in both periods. As discussed in section 3.3 , we rule out this solution by requiring that the manager's compensation does not hit the ceiling in at least one period.
} 
OCP is satisfied only if the price change (conditional on the project's success) in period 1 equals the price change (conditional on the project's success) in period 2. Because stock prices are forward looking, and because success or failure in one period is likely to have implications for expected cash flows many periods in the future, this condition will rarely be satisfied.

To clarify the intuition let us now turn to two settings with fewer parameters. In section 4.2, the investment $\mathrm{K}$ is $\$ 0$ and the focus is on comparing earnings and prices. In section 4.3, the investment is non-zero and the focus is on comparing cash flows and earnings.

\subsection{Problems with Price-Based Plans}

The objective of this setting is to highlight, in the simplest possible way, the problems associated with price-based compensation plans. To simplify the analysis we assume $\mathrm{C}_{\mathrm{S} 1}=\mathrm{C}_{\mathrm{S} 2}=$ $\mathrm{C}_{\mathrm{S}}, \mathrm{C}_{\mathrm{F} 1}=\mathrm{C}_{\mathrm{F} 2}=\mathrm{C}_{\mathrm{F}}$, and $\mathrm{K}=0$.

Cash-based plan: Since cash flows are the same in both periods and $\mathrm{K}=0, \mathrm{C}_{\mathrm{S} 1}-\mathrm{K}=\mathrm{C}_{\mathrm{S}}=\mathrm{C}_{\mathrm{S} 2}$, which is also the optimality condition for cash. Thus a cash-based compensation function can achieve the optimum solution under a generalized contract.

Earnings-based plan: Since cash flows are the same in both periods and $\mathrm{K}=0, \mathrm{C}_{\mathrm{S1}}-\delta \mathrm{K}=\mathrm{C}_{\mathrm{S}}=$ $\mathrm{C}_{\mathrm{S} 2}-(1-\delta) \mathrm{K}$, which is also the optimality condition for earnings. In this case there is no difference between earnings and cash flows.

Price-based plan: Inducing the manager to take the desired action with a price-based compensation plan is more costly in this setting than using either a cash-based or an earningsbased plan. To see this, note that the stock-price change following success in period 1 is larger than the stock-price change following success in period 2 because the price change in period 1 includes the expectation of cash flows in period 2. Thus, if the manager's compensation is based on change in price and the same function is used in both periods, then the manager will be paid more in period 1 than in period 2. But, the agent's individual rationality constraints (IR1 and IR2) must be met in each period. Thus, even if IR2 is binding (i.e., the manager is paid his reservation wage in period 2), IR1 will have slack. That is the manager will be "overpaid" in relation to his reservation wage in period 1. In contrast, under the generalized contract, both IR1 and IR2 are binding.

There would, of course, be no overpayment if the compensation function in period 1 could be different from the compensation function in period 2. For example, if the compensation 
is less sensitive to price change in period 1 than in period 2, then the agent would be paid the same amount at the end of periods 1 and 2, even if the price change in period 1 is larger. As discussed earlier, allowing the compensation function to change each period renders the debate regarding the choice among price, earnings, and cash-flow-based compensation moot. By changing the function, the principal could, in effect, construct accounting earnings from the price changes.

When the project is anticipated: We have assumed so far that the project is a surprise to the market. The greater the extent to which the project is anticipated, the lower is the price increase when the project succeeds in period 1 and lesser is the amount of overpayment in period 1 under a price-based contract. The anticipation of the project, however, does not eliminate the contract design problem, it merely shifts it to earlier periods.

Partial anticipation of the project raises another problem when there are more than two possible outcomes in period 1. With only two outcomes, a price increase implies success and decrease implies failure. When there are more than two outcomes, one needs to know exactly what were the market's prior expectations to infer the underlying state from the observed price change and the contract requires recalibration as the degree of anticipation changes.

When the principal can commit to a two-period contract: We now show that the result that the agent is overpaid in period 1 is not sensitive to the assumption that principal commits only to a one-period contract. Let us see what the principal can and cannot do if she could commit to a two-period contract. A contract that underpays the agent in period 1, and makes up for it in period 2 is now feasible, because the principal can credibly commit to continue in period 2. However, a contract that overpays the agent in period 1 and underpays the agent in period 2 is not sensible because the agent can quit at the end of period 1 . The agent cannot be forced to work in period 2; he does not commit to a two-period contract, only the principal does. In our setting the price change is greater in period 1 than in period 2, so the agent is overpaid in period 1 if a stationary price-based compensation contract is used. Since the agent must get at least his reservation utility in period 2 , he is overpaid overall. If the sub-optimality were because the price change was less in period 1 than in period 2, then the principal's ability to commit to a twoperiod contract would help her. A price-based function could be chosen such that with lower 
price change in period 1 , the agent would be paid less than his reservation utility in period 1 , which would be offset by overpayment in period 2, so that overall there is no overpayment.

\subsection{Problems with Cash Flow-Based Plans}

This setting is the same as the previous setting except that investment $\mathrm{K}$ required in the project is now not zero. It highlights, in the simplest possible way, the problems with cash-based compensation. It shows how the accrual process (matching concept) measures delivered performance better than cash flows and change in stock price.

Cash-based plan: Since the project requires a cash investment in period 1 and requires no net investment in period 2, the cash flows are skewed. However, the agent must work equally hard in both periods and must get at least his reservation utility in each period. If a cash-based plan gives him his reservation utility in period 1, it will overpay him in period 2 because the net cash flow in period 2 is higher. Technically, there is no monotonic function $f_{C}$ such that $f_{C}\left(C_{S}-K\right)=f_{C}\left(C_{S}\right)$ (Note that we assume the compensation does not hit the ceiling in at least one period). Since IR1 must be met, a cash-based plan will overpay the agent in period 2. The extent of overpayment will increase as $\mathrm{K}$ increases. So a cash-based compensation plan would pay him his reservation wage in period 1 and overpay him in period 2.

The overpayment under cash-based compensation could be reduced if the principal could commit to a two-period contract. Then, a cash-based function could be chosen such that with lower cash flows in period 1, the agent would be somewhat underpaid in period 1, with an offsetting increase in period 2. However, in settings where there are positive cash flows initially but negative cash later such as in warranty and insurance contracts, the agent would be overpaid even if the principal could commit to long-term contracts.

Earnings-based plan: It is logical to assume that to match the costs with revenues recognized in that period accountants will depreciate the cost $\mathrm{K}$ incurred in period 1 over period 1 as well as period 2. Since the investment has a useful life of two years and is expected to be equally useful

in both periods, it is also logical to assume that accountants would pick $\delta$ to be $1 / 2$, i.e., they would depreciate only half of the cost of the project in period 1 . Thus $E_{S 1}=C_{S}-K / 2=E_{S 2}$ and the optimal generalized contract can be mimicked with an earnings-based plan.

Price-based plan: The addition of a required investment in the project does not alter the conclusion from our analysis. The stock-price change following success in period 1 is larger than 
the stock-price change following success in period 2 because the stock-price change in period 1 still includes the expectation of cash flows in period 2. Thus to induce the manager to take the desired action in both periods, it is again necessary in this setting to overpay the manager in period 1 .

In summary, assuming an investment $\mathrm{K}$ in the project, a cash-based contract overpays the agent in period 2, a price-based contract overpays the agent in period 1, and an earnings-based contract pays optimally because the matching principle makes earnings a better measure of delivered performance.

\subsection{Depreciation of Sunk Costs}

Another key insight here is that it is not optimal to depreciate the investment fully even if it is a sunk cost; $\mathrm{K}(1-\delta)$ will be shown on the books as an asset at the end of period 1 . Thus the application of matching concept of accrual accounting generates periodic income that is a "reasonable" measure of performance delivered in that period. We hasten to add that this clearly depends on whether the accountants' depreciation assumptions are reasonable. If depreciation is too little in period 1, then first period earnings will be too high, resulting in overpayment to the agent in period 1. If accounting depreciation is too high in period 1, then the earnings in period 2 will be inflated, resulting in overpayment in period 2. To our knowledge, this justification of allocating sunk costs is different from arguments made in the literature.

\section{Conclusion}

The compensation contract between a large publicly-traded firm's senior managers and its shareholders is an ideal candidate for examining the role of accounting earnings. Stock prices, cash flows, and earnings of such firms are easily available and the senior managers make decisions that influence overall firm performance. Still earnings-based bonus plans are an important component of CEO compensation. Why not use cash flows or price changes, which can be readily audited, for decision making and control? What value does the accrual process add?

The "matching principle" is a fundamental tenet of accounting. We show that the application of this concept leads to robust and simple compensation contracts. The contracts are robust in the sense that they do not depend on the extent to which the market anticipates future 
delivery of performance and are not susceptible to unforeseen events that alter expectations of future performance. They are simple in the sense that they do not require period-by-period changes in pay-for-performance sensitivity when the underlying production function does not change from period to period. Stock prices, in contrast, anticipate future delivery of performance and are thus often used in conjunction with mechanisms that extend the contracting horizon such as vesting periods.

Earnings are a poor measure of delivered performance when accountants do not apply the matching concept due to their conservatism in settings where it is difficult to verify future cash flows such as in intangible intensive firms. Firms are then forced to seek alternative measures of delivered performance. Our objective is to restore balance to comparisons between stock-price changes and earnings as performance measures by pointing out that earnings provide separate and useful information, even in the presence of stock-price and cash flow data. Neither earnings nor stock-prices are perfect performance measures.

The use of earnings in CEO compensation contracts raises an important question about the objective that should guide accounting standard setters in making decisions about disclosure standards. Our research suggests an accounting accrual process that is designed to enhance the correlation between earnings and stock-price changes might weaken the matching property of earnings. The lag between stock prices and earnings is inevitable even in the absence of conservatism if earnings are to match delivered performance. If we make earnings contemporaneous with price changes to increase the correlation between the two, then we will lose a useful measure of delivered performance. 


\section{References}

Chiappori, Pierre-Andre, Ines Macho, Patrick Rey, and Bernard Salanie, "Repeated Moral Hazard: The Role of Memory Commitment, and the Access to Capital Markets," European Economic Review 38 (1994) 1527 - 1553.

Dye, Ronald A., 1985, Optimal Length of Labor Contracts, International Economic Review 26, 251-270.

Dye, Ronald A., 1988, Earnings Management in an Overlapping Generations Model, Journal of Accounting Research 26, 195-235.

Easton, Peter D.; Harris, Trevor S.; Ohlson, James A., "Aggregate Accounting Earnings Can Explain Most of Security Returns: The Case of Long Return Intervals," Journal of Accounting and Economics; v15 n2-3 June-Sept. 1992, pp. 119-142.

Fudenberg, Drew, Bengt Holmstrom, and Paul Milgrom, "Short-term Contracts and Long-term Agency Relationships," Journal of Economic Theory, 51, 1990, pp: 1 - 31.

Lambert, Richard A., "Long-term Contracts and Moral Hazard," Bell Journal of Economics, v14 n2 Autumn 1983, pp. 441 - 452.

Paul, Jonathan M., "On the Efficiency of Stock-based Compensation," Review of Financial Studies; v5 n3 1992, pp. 471 - 502.

Radner, Roy, "Repeated Principal-Agent Games with Discounting," Econometrica 53 (5, 1985): 1173 - 1198.

Reichelstein, Stefan, 1997a, Investment Decisions and Managerial Performance Evaluation, Review of Accounting Studies, Vol.2 (2) 1997

Reichelstein, Stefan, 1999, Providing Managerial Incentives: Cash Flows versus Accrual Accounting, Forthcoming in the Review of Accounting Studies

Rey, Patrick, and Bernard Salanie, "Long-term, Short-term, and Renegotiation: On the Value of Commitment in Contracting," Econometrica, Vol 58. No. 3 (May, 1990) 597 - 619.

Rogerson, William P., 1985, Repeated Moral Hazard, Econometrica 53, 69-76.

Rogerson, William P., 1997, Intertemporal Cost Allocation and Managerial Investment Incentives: A Theory Explaining the Use of Economic Value Added as a Performance Measure, Journal of Political Economy, vol 105 no.4, pp 770-795.

Rubinstein, Ariel and Yaari, Menahem E., "Repeated Insurance Contracts and Moral Hazard," Journal of Economic Theory; v30 n1 June 1983, pp. 74 - 97.

Sloan, Richard G., "Accounting Earnings and Top Executive Compensation," Journal of Accounting and Economics v16 n1 - 2 - 3 Jan. - April - July 1993, pp. 55 - 100. 


\section{Appendix I}

\subsection{Price Change-Based Compensation}

This section derives the condition under which a price-change-based compensation plan can implement the solution obtained if the compensation plan was not constrained to be based on price change over a period. This condition is referred to as the Optimality Condition for Price (OCP).

Let $\mathrm{d}_{\mathrm{WS}}=\mathrm{W}_{\mathrm{S} 1}-\mathrm{W}_{\mathrm{S} 2}$ and $\mathrm{d}_{\mathrm{WF}}=\mathrm{W}_{\mathrm{F} 1}-\mathrm{W}_{\mathrm{F} 2}$. We know that the under the optimal unconstrained solution $d_{W S}=d_{W F}=0$. Let us see derive the conditions under which this is feasible under a price-change-based compensation plan.

We know,

$$
\begin{aligned}
& \mathrm{P}_{\mathrm{S} 2}=\mathrm{P}_{0}-\mathrm{K}+\mathrm{C}_{\mathrm{S} 1}-\mathrm{W}_{\mathrm{S} 1}+\mathrm{C}_{\mathrm{S} 2}-\mathrm{W}_{\mathrm{S} 2} \\
& \mathrm{P}_{\mathrm{F} 2}=\mathrm{P}_{0}-\mathrm{K}+\mathrm{C}_{\mathrm{S} 1}-\mathrm{W}_{\mathrm{S} 1}+\mathrm{C}_{\mathrm{F} 2}-\mathrm{W}_{\mathrm{F} 2} \\
& \mathrm{P}_{\mathrm{S} 1}=\mathrm{P}_{0}-\mathrm{K}+\mathrm{C}_{\mathrm{S} 1}-\mathrm{W}_{\mathrm{S} 1}+\mathrm{q}_{\mathrm{H}}\left(\mathrm{C}_{\mathrm{S} 2}-\mathrm{W}_{\mathrm{S} 2}\right)+\left(1-\mathrm{q}_{\mathrm{H}}\right)\left(\mathrm{C}_{\mathrm{F} 2}-\mathrm{W}_{\mathrm{F} 2}\right) \\
& \mathrm{P}_{\mathrm{F} 1}=\mathrm{P}_{0}-\mathrm{K}+\mathrm{C}_{\mathrm{F} 1}-\mathrm{W}_{\mathrm{F} 1}
\end{aligned}
$$

Price change if the project fails in period 1

$$
=\mathrm{P}_{\mathrm{F} 1}-\mathrm{P}_{0}=-\mathrm{K}+\mathrm{C}_{\mathrm{F} 1}-\mathrm{W}_{\mathrm{F} 1}
$$

Price change if the project succeeds in period 1

$$
=\mathrm{P}_{\mathrm{S} 1}-\mathrm{P}_{0}=-\mathrm{K}+\mathrm{C}_{\mathrm{S} 1}-\mathrm{W}_{\mathrm{S} 1}+\mathrm{q}_{\mathrm{H}}\left(\mathrm{C}_{\mathrm{S} 2}-\mathrm{W}_{\mathrm{S} 2}\right)+\left(1-\mathrm{q}_{\mathrm{H}}\right)\left(\mathrm{C}_{\mathrm{F} 2}-\mathrm{W}_{\mathrm{F} 2}\right)
$$

Price change if the project fails in period 2

$$
=\mathrm{P}_{\mathrm{F} 2}-\mathrm{P}_{\mathrm{S} 1}=-\mathrm{q}_{\mathrm{H}}\left[\left(\mathrm{C}_{\mathrm{S} 2}-\mathrm{W}_{\mathrm{S} 2}\right)-\left(\mathrm{C}_{\mathrm{F} 2}-\mathrm{W}_{\mathrm{F} 2}\right)\right]
$$

Price change when project succeeds in period 2

$$
=\mathrm{P}_{\mathrm{S} 2}-\mathrm{P}_{\mathrm{S} 1}=\left(1-\mathrm{q}_{\mathrm{H}}\right)\left[\left(\mathrm{C}_{\mathrm{S} 2}-\mathrm{W}_{\mathrm{S} 2}\right)-\left(\mathrm{C}_{\mathrm{F} 2}-\mathrm{W}_{\mathrm{F} 2}\right)\right]
$$

Difference in price changes if the project succeeds $=d_{P S}=\left(P_{S 1}-P_{0}\right)-\left(P_{S 2}-P_{S 1}\right)$

$$
\begin{aligned}
= & \left\{-\mathrm{K}+\mathrm{C}_{\mathrm{S} 1}-\mathrm{W}_{\mathrm{S} 1}+\mathrm{q}_{\mathrm{H}}\left(\mathrm{C}_{\mathrm{S} 2}-\mathrm{W}_{\mathrm{S} 2}\right)+\left(1-\mathrm{q}_{\mathrm{H}}\right)\left(\mathrm{C}_{\mathrm{F} 2}-\mathrm{W}_{\mathrm{F} 2}\right)\right\}-\left\{( 1 - \mathrm { q } _ { \mathrm { H } } ) \left[\left(\mathrm{C}_{\mathrm{S} 2}-\mathrm{W}_{\mathrm{S} 2}\right)-\left(\mathrm{C}_{\mathrm{F} 2}-\right.\right.\right. \\
& \left.\left.\left.\mathrm{W}_{\mathrm{F} 2}\right)\right]\right\} \\
= & {\left[\mathrm{C}_{\mathrm{S} 1}-\mathrm{W}_{\mathrm{S} 1}+\left(2 \mathrm{q}_{\mathrm{H}}-1\right)\left(\mathrm{C}_{\mathrm{S} 2}-\mathrm{W}_{\mathrm{S} 2}\right)+2\left(1-\mathrm{q}_{\mathrm{H}}\right)\left(\mathrm{C}_{\mathrm{F} 2}-\mathrm{W}_{\mathrm{F} 2}\right)\right]-\mathrm{K} } \\
= & 2\left[\mathrm{q}_{\mathrm{H}}\left(\mathrm{C}_{\mathrm{S} 2}-\mathrm{W}_{\mathrm{S} 2}\right)+\left(1-\mathrm{q}_{\mathrm{H}}\right)\left(\mathrm{C}_{\mathrm{F} 2}-\mathrm{W}_{\mathrm{F} 2}\right)\right]+\left(\mathrm{C}_{\mathrm{S} 1}-\mathrm{W}_{\mathrm{S} 1}\right)-\left(\mathrm{C}_{\mathrm{S} 2}-\mathrm{W}_{\mathrm{S} 2}\right)-\mathrm{K}
\end{aligned}
$$


$=2\left[\mathrm{q}_{\mathrm{H}}\left(\mathrm{C}_{\mathrm{S} 2}-\mathrm{W}_{\mathrm{S} 2}\right)+\left(1-\mathrm{q}_{\mathrm{H}}\right)\left(\mathrm{C}_{\mathrm{F} 2}-\mathrm{W}_{\mathrm{F} 2}\right)\right]+\left(\mathrm{C}_{\mathrm{S} 1}-\mathrm{C}_{\mathrm{S} 2}\right)-\mathrm{d}_{\mathrm{WS}}-\mathrm{K}$

So $\mathrm{d}_{\mathrm{PS}}+\mathrm{d}_{\mathrm{WS}}=2\left[\mathrm{q}_{\mathrm{H}}\left(\mathrm{C}_{\mathrm{S} 2}-\mathrm{W}_{\mathrm{S} 2}\right)+\left(1-\mathrm{q}_{\mathrm{H}}\right)\left(\mathrm{C}_{\mathrm{F} 2}-\mathrm{W}_{\mathrm{F} 2}\right)\right]+\left(\mathrm{C}_{\mathrm{S} 1}-\mathrm{C}_{\mathrm{S} 2}\right)-\mathrm{K}$

Difference in price changes if the project fails $=\mathrm{d}_{\mathrm{PF}}=\left(\mathrm{P}_{\mathrm{F} 1}-\mathrm{P}_{0}\right)-\left(\mathrm{P}_{\mathrm{F} 2}-\mathrm{P}_{\mathrm{F} 1}\right)$

$$
\begin{aligned}
& =\left[\mathrm{C}_{\mathrm{F} 1}-\mathrm{W}_{\mathrm{F} 1}-\mathrm{K}\right]-\left[-\mathrm{q}_{\mathrm{H}}\left[\left(\mathrm{C}_{\mathrm{S} 2}-\mathrm{W}_{\mathrm{S} 2}\right)-\left(\mathrm{C}_{\mathrm{F} 2}-\mathrm{W}_{\mathrm{F} 2}\right)\right]\right] \\
& =\mathrm{q}_{\mathrm{H}}\left[\left(\mathrm{C}_{\mathrm{S} 2}-\mathrm{W}_{\mathrm{S} 2}\right)-\left(\mathrm{C}_{\mathrm{F} 2}-\mathrm{W}_{\mathrm{F} 2}\right)\right]+\left(\mathrm{C}_{\mathrm{F} 1}-\mathrm{W}_{\mathrm{F} 1}\right)-\mathrm{K}
\end{aligned}
$$

In the optimal solution with unconstrained compensation functions, both $\mathrm{d}_{\mathrm{Ws}}$ and $\mathrm{d}_{\mathrm{WF}}$ are zero. This requires that $d_{P S}$ be zero. ( $d_{\mathrm{WF}}$ being zero does not imply that $d_{\mathrm{PF}}$ is zero, because we allow the compensation to hit the floor in both periods. If we assume that $d_{\mathrm{PF}}$ is also zero, then our results are easier to prove but are less general.)

Suppose $\mathrm{d}_{\mathrm{PS}}=\mathrm{d}_{\mathrm{WS}}=\mathrm{d}_{\mathrm{WF}}=0$.

$$
\mathrm{d}_{\mathrm{PS}}+\mathrm{d}_{\mathrm{WS}}=0 \text { implies } 2\left[\mathrm{q}_{\mathrm{H}}\left(\mathrm{C}_{\mathrm{S} 2}-\mathrm{W}_{\mathrm{S} 2}\right)+\left(1-\mathrm{q}_{\mathrm{H}}\right)\left(\mathrm{C}_{\mathrm{F} 2}-\mathrm{W}_{\mathrm{F} 2}\right)\right]+\left(\mathrm{C}_{\mathrm{S} 1}-\mathrm{C}_{\mathrm{S} 2}\right)-\mathrm{K}=0 \quad \text { (OCP) }
$$

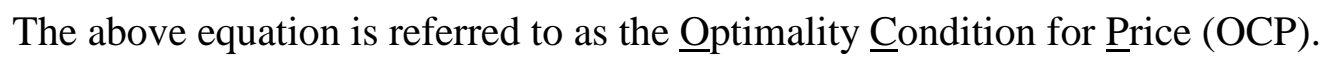




\section{Notation}

1 and 2 refer to periods 1 and 2 respectively.

$\mathrm{S}$ and F refer to "success" and "failure" respectively.

If the project fails in period 1 , it is not continued in period 2.

$\mathrm{a}_{\mathrm{H}}, \mathrm{a}_{\mathrm{L}}$

$\mathrm{qH}_{\mathrm{H}}$

$\mathrm{q}_{\mathrm{L}}$

$\mathrm{R}$

$\mathrm{U}$

$\mathrm{D}$

$\mathrm{C}_{\mathrm{S} 1}, \mathrm{C}_{\mathrm{S} 2}$

$\mathrm{C}_{\mathrm{F} 1}, \mathrm{C}_{\mathrm{F} 2}$

$\mathrm{K}$

$\delta$

$\mathrm{E}_{\mathrm{S} 1}$

$\mathrm{E}_{\mathrm{F} 1}$

$\mathrm{E}_{\mathrm{S} 2}$

$\mathrm{E}_{\mathrm{F} 2}$

$\mathrm{W}_{\mathrm{S} 1}, \mathrm{~W}_{\mathrm{S} 2}$

$\mathrm{W}_{\mathrm{F} 1}, \mathrm{~W}_{\mathrm{F} 2}$ :

$\mathrm{f}_{\mathrm{C}}$

$f_{E}$

$f_{P}$

$\mathrm{P}_{0}$

$\mathrm{P}_{\mathrm{S} 1}$

$\mathrm{P}_{\mathrm{F} 1}$

$\mathrm{P}_{\mathrm{S} 2}$

$\mathrm{P}_{\mathrm{F} 2}$

IR

IC

PR

OCP

OCC

OCE agent's high and low effort

probability of success in a period if agent takes $\mathrm{a}_{\mathrm{H}}$ in that period.

probability of failure if agent takes $a_{L}$ in that period.

agent's reservation utility

agent's utility function for compensation

agent's disutility function for effort

cash flow from the project at the end of a period if the project succeeds.

cash flow from the project at the end of a period if the project fails.

investment (cash outlay) required for the project.

fraction of cash outlay $\mathrm{K}$ which is expensed in period 1.

earnings if the project succeeds in period 1 (before subtracting agent's compensation) $=\mathrm{C}_{\mathrm{S} 1}-\mathrm{K}^{*} \delta$

earnings if the project fails in period 1 (before subtracting agent's compensation) $=\mathrm{C}_{\mathrm{F} 1}-\mathrm{K}^{*} \delta$

earnings if the project succeeds in period 2 (before subtracting agent's compensation $)=\mathrm{C}_{\mathrm{S} 2}-\mathrm{K}^{*}(1-\delta)$

earnings if the project fails in period 1 (before subtracting agent's compensation $)=\mathrm{C}_{\mathrm{F} 2}-\mathrm{K}^{*}(1-\delta)$

agent's compensation at the end of a period if the project succeeds.

agent's compensation at the end of a period if the project fails.

stationary cash-flow-based compensation function

stationary earnings-based compensation function

stationary stock-price-based compensation function

firm's market value before the project is announced

firm's market value at the end of period 1 if the project succeeds $=\mathrm{P}_{0}-\mathrm{K}+\left(\mathrm{C}_{\mathrm{S} 1}-\mathrm{W}_{\mathrm{S} 1}\right)+\mathrm{q}_{\mathrm{H}} *\left(\mathrm{C}_{\mathrm{S} 2}-\mathrm{W}_{\mathrm{S} 2}\right)+\left(1-\mathrm{q}_{\mathrm{H}}\right) *\left(\mathrm{C}_{\mathrm{F} 2}-\mathrm{W}_{\mathrm{F} 2}\right)$

firm's market value at the end of period 1 if the project fails

$$
=\mathrm{P}_{0}-\mathrm{K}+\mathrm{C}_{\mathrm{F} 1}-\mathrm{W}_{\mathrm{F} 1}
$$

firm's market value at the end of period 1 if the project succeeds

$$
=\mathrm{P}_{0}-\mathrm{K}+\left(\mathrm{C}_{\mathrm{S} 1}-\mathrm{W}_{\mathrm{S} 1}\right)+\left(\mathrm{C}_{\mathrm{S} 2}-\mathrm{W}_{\mathrm{S} 2}\right)
$$

firm's market value at the end of period 1 if the project fails

$$
=\mathrm{P}_{0}-\mathrm{K}+\left(\mathrm{C}_{\mathrm{S} 1}-\mathrm{W}_{\mathrm{S} 1}\right)+\left(\mathrm{C}_{\mathrm{F} 2}-\mathrm{W}_{\mathrm{F} 2}\right)
$$

individual rationality constraint

incentive compatibility constraint

principal's rationality constraint

optimality condition for price

optimality condition for cash

optimality condition for earnings 
Figure 1: The Road Construction Example

(These graphs are drawn assuming a zero discount rate and probability of cost overrun of 0.5.)

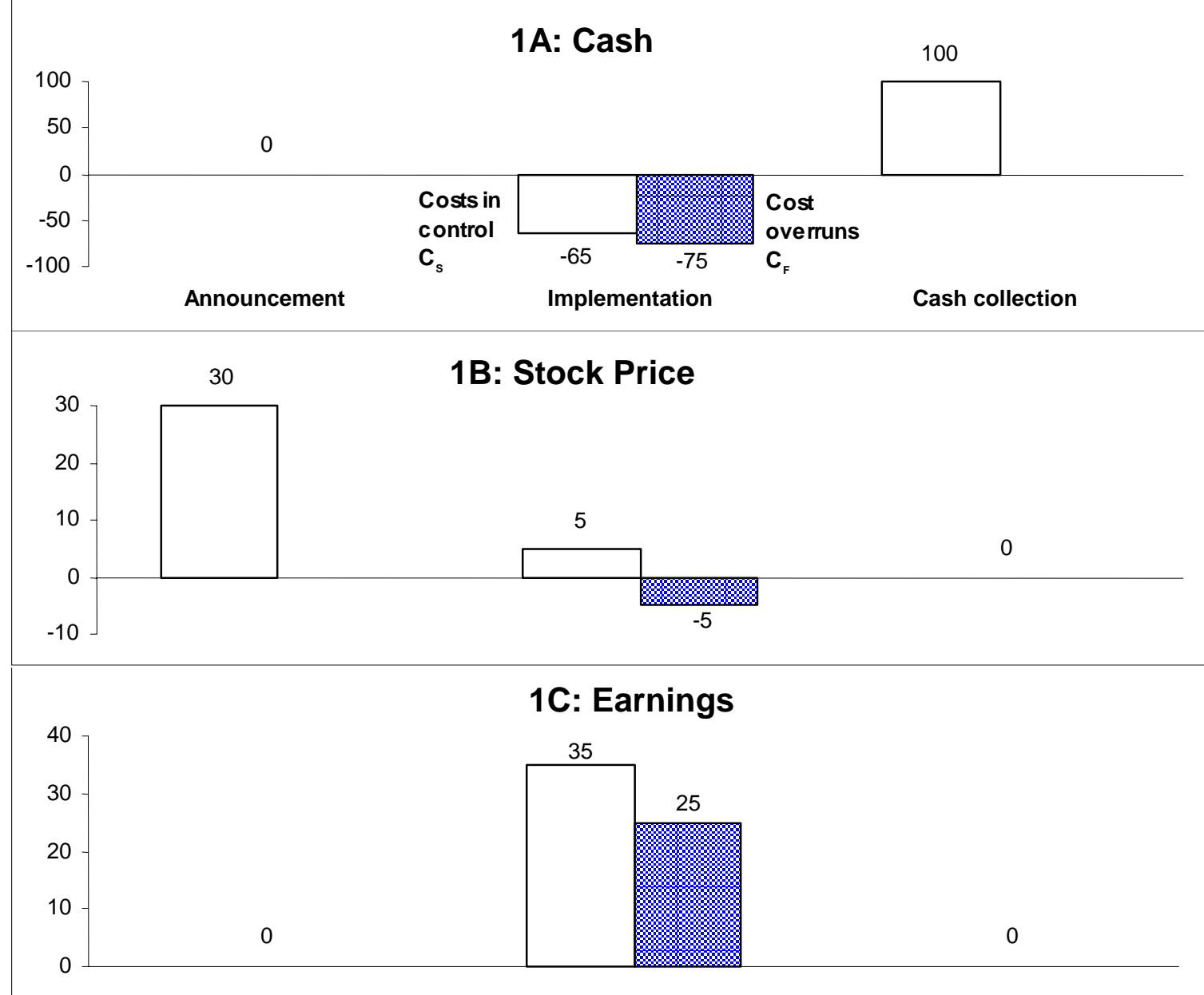

1D: Compensation for Controlling Costs

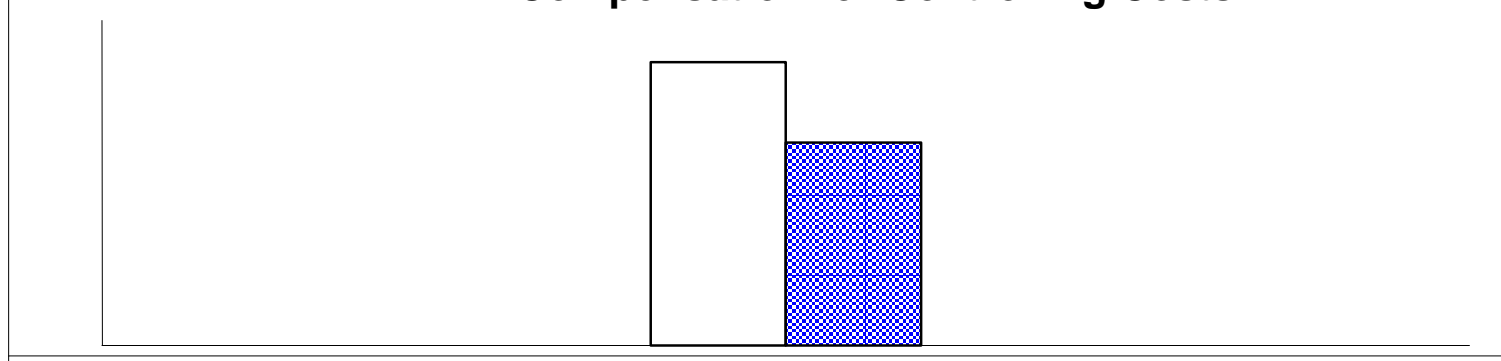

1E: Compensation for Winning the Contract 
Figure 2: Sequence of Events

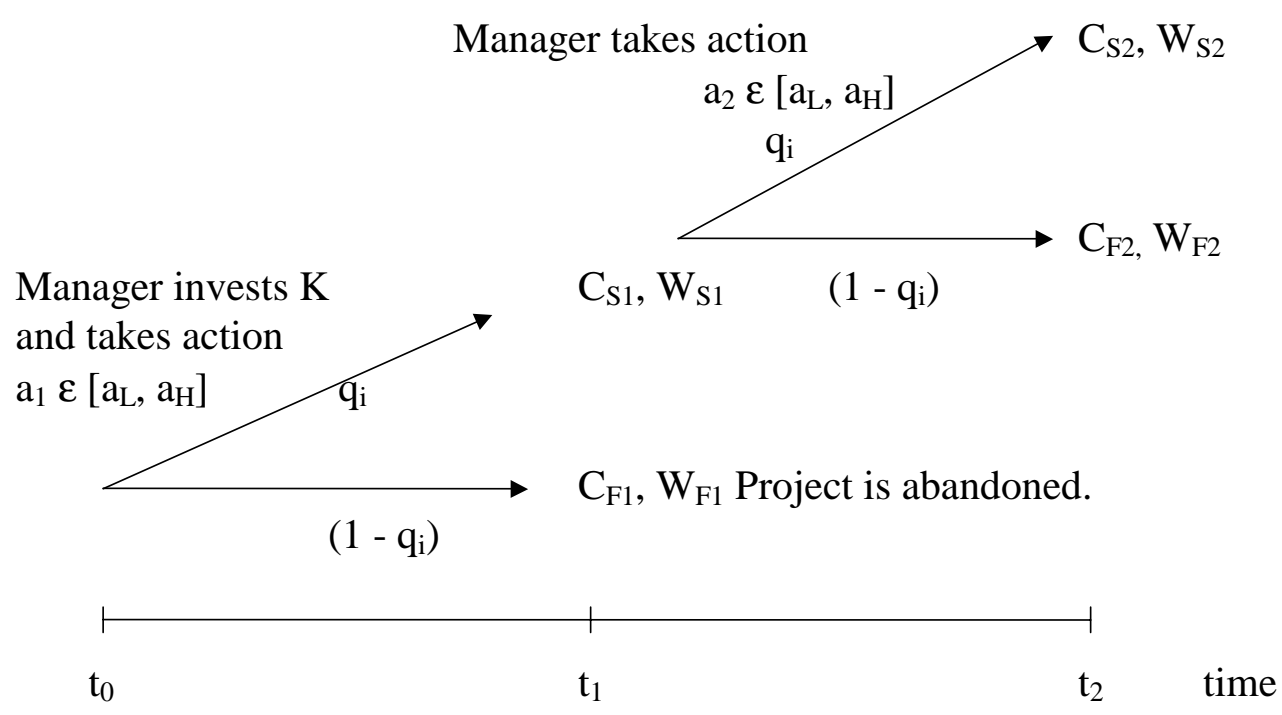

C denotes project's cash flows.

$\mathrm{W}$ denotes manager's wage. 
Figure 3: Compensation Function

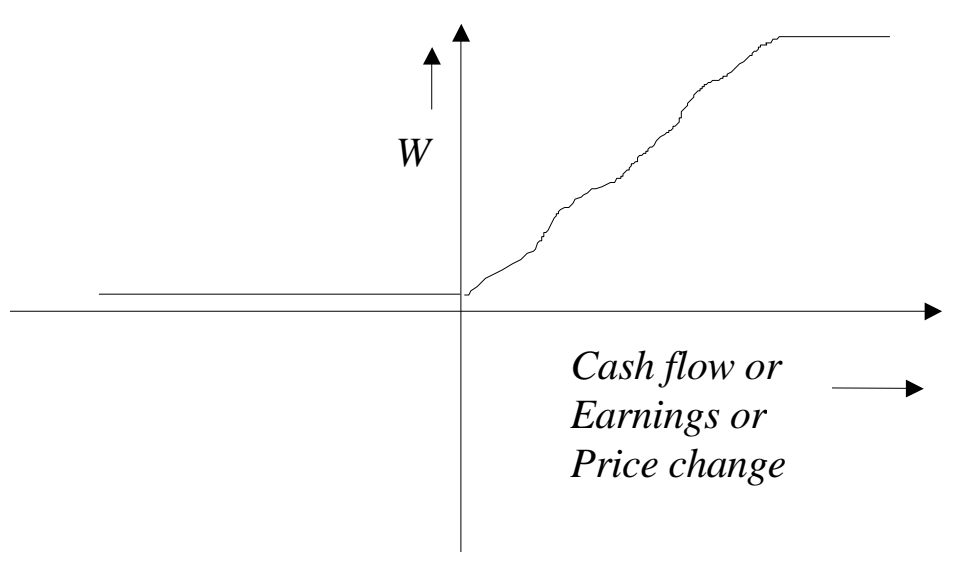

